\title{
Patiëntenvoorlichting
}

\section{PV 28 Verruciform xanthoom}

Een verruciform xanthoom (verruca is het Latijnse woord voor wrat, terwijl xanthoom "vetachtig" betekent) is een tamelijk zeldzame, goedaardige afwijking van het mondslijmvlies. De oorzaak is onbekend. Er is geen bewijs voor een virus als oorzaak. De afwijking is niet besmettelijk.

Een verruciform xanthoom uit zich meestal als een enigszins gelige, wratachtige laesie. De afwijking treedt meestal pas op middelbare leeftijd op en veroorzaakt weinig of geen klachten. Een verruciform xanthoom komt soms op het tandvlees voor, maar voorkomen op andere plaatsen in de mond is niet ongewoon. Een verruciform xanthoom wordt zelden groter dan 1-2 cm. De diagnose kan niet met zekerheid met alleen het blote oog worden gesteld. Bij het vermoeden op een verruciform xanthoom zal dan ook in principe een weefselstukje voor onderzoek door de patholoog moeten worden weggenomen. In de praktijk is het meestal mogelijk om voor dit doel de laesie in haar geheel te verwijderen, waardoor er geen tweede ingreep meer behoeft te worden uitgevoerd. Terugkeren van de afwijking na verwijdering is eigenlijk nooit beschreven.

\section{Wat kunt u zelf doen?}

U kunt bij het vermoeden op aanwezigheid van een verruciform xanthoom zelf niets doen. Gelukkig gaat de afwijking niet met pijn of ongemak gepaard en is er geen zorg voor besmettelijkheid. Aangezien de afwijking na verwijdering zelden of nooit terugkeert, is geen speciale controle door tandarts of mondhygiënist vereist.
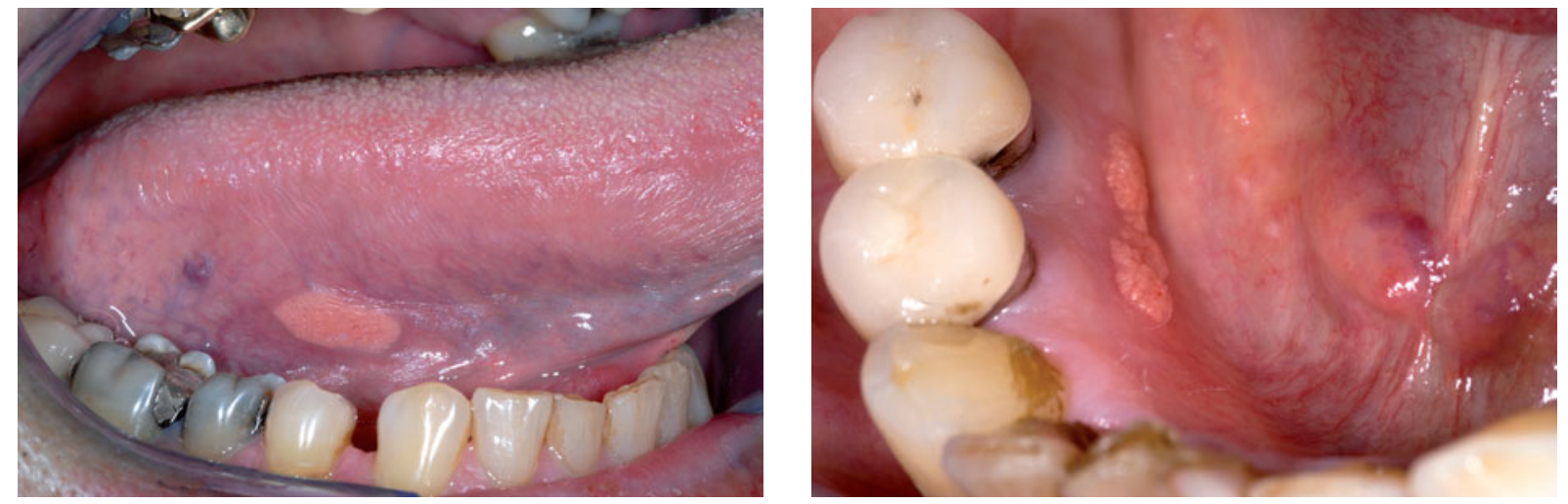